\title{
DRIFT-ICE ABRASION MARKS ALONG ROCKY SHORES
}

\author{
By JEAN-Claude Dionne \\ (Department of Geography and Centre d'Études Nordiques, Université Laval, Québec, \\ Province Québec G1K 7P4, Canada)
}

ABstract. Drift-ice abrasion marks are common along present-day rocky shorelines in cold regions. They include polished surfaces, scratches, striations, small grooves, and minor friction cracks. Most are found on relatively soft rocks like shale, sandstone, limestone, dolomite, and basalt, and occasionally on harder rocks like granite and gneiss. They were made by rock fragments frozen at the base of ice cover or by ice floes pushed onshore by wind or dragged along the bottom by waves, tides, and currents. They are found both in the modern and Pleistocene marine, lacustrine, and fluvial environments. Along the Hudson Bay eastern shoreline, these abrasion marks are superimposed on glacially polished and striated surfaces. Along the St. Lawrence Estuary, they are more common on boulders in the tidal zone. Characteristics of drift-ice abrasion marks are described and their significance is pointed out.

RÉsUMÉ. Les marques d'abrasion glacielles le long des rivages rocheux. Les marques d'abrasion glacielles abondent sur les rivages rocheux actuels des régions froides. Elles comprennent des surfaces polies, des égratignures diverses, des striures, des rainures et des marques de chocs mineures. On les trouve principalement sur des roches relativement tendres comme les schistes, grès, calcaires, dolomie et basalte, et occasionnellement, sur des roches plus résistantes comme le granite et le gneiss. Elles sont faites d'année en année par des cailloux ou des fragments rocheux insérés à la base du couvert de glace ou dans des glaçons qui sont soit poussés sur le rivage par le vent ou les pressions exercées par la banquise ou le couvert de glace, soit

\section{INTRODUCTION}

Drift-ice abrasion marks are common along rocky shores in cold regions. Although they have been reported several times from many regions during the last century (Dionne, 1970), their importance has been pointed out only recently, at least in English and French (McLellan, 1971; Dionne, 1973; Laverdière and others, 1981; Dionne and others, 1983). In the past, drift-ice abrasion marks were generally considered of little interest. In text-books, they are usually classified with other erratic abrasion marks on rock surfaces made by solifluction, landslides, mud flows, and avalanches (Embleton and King, 1975, p. 184).

In coastal areas glaciated during the Quaternary, such abrasion marks are sometimes confused with glacial abrasion features. As a result, some authors reported multi-directional striations, sometimes up to seven or eight directions in the same locality, and they attributed the various sets to changes in glacier-flow direction.

Recent field work along the east coast of Hudson Bay in sub-Arctic Quebec shows that several sets of striations observed along present-day rocky shorelines are drift-ice abrasion marks (Dionne and others, 1983). The purpose of this paper is to report and characterize abrasion marks made by drift ice, to discuss briefly their significance, and to focus the attention of Quaternary geologists on a neglected topic. déplacés par les vagues, la marée et les courants. On les trouve à la fois dans les milieux marin, lacustre et fluviatile, actuels et anciens (quaternaires). Le long de la côte est de la mer d'Hudson, ces diverses marques d'abrasion sont superposées à des surfaces glaciaires polies et striées. Le long des rives de l'estuaire du Saint-Laurent, on les trouve principalement sur des blocs d'estran. Les carctéristiques des marques d'abrasion glacielles sont indiquées et leur signification est soulignée.

Zusammenfassung. Abrasionsnarben durch Drifteis längs felsiger Küsten. Abrasionsnarben, hervorgerufen durch Drifteis, sind hăufig längs derzeit felsiger Küstenlinien in kalten Regionen zu finden; sie kommen als polierte Oberflächen, Schrammen, Riefen, kleine Rinnen und Reibungsrisse vor. Meist treten sie an relativ weichen Gesteinen wie Schiefer, Sandstein, Kalk, Dolomit und Basalt, gelgentlich aber auch an härteren Gesteinen wie Granit und Gneiss auf. Sie stammen von Felsstücken, die in die Unterseite von Eisdecken eingefroren sind, oder von Eisschollen, die vom Wind ans Ufer gestossen oder von Wellen, Gezeiten und Strömungen lăngs des Grundes herangeschleppt werden. Sie treten sowohl an rezenten wie an pleistozănen Meeres, Seen- und Flussufern auf. Lăngs des Ostuferns der Hudson Bay überlagern diese Abrasionsnarben glazial polierte und geriefte Oberflăchen. Lăngs des Ästuars des St. Lawrence-Stromes findet man sie hăufiger an Felsblöcken im Gezeitenbereich. Die Kennzeichen für Abrasionsnarben des Drifteises werden beschrieben und auf ihre Bedeutung wird eingegangen.

\section{DRIFT-ICE ABRASION MARKS}

The various drift-ice abrasion marks include polished surfaces, scratches, striations, small grooves, and even minor friction cracks (Laverdière and others, 1981). These marks usually occur on relatively soft rocks such as shale, sandstone, limestone, dolomite, and basalt, and occasionally on harder rocks such as granite and gneiss.

\section{Polished surfaces}

Polished surfaces resulting from abrasion by drift ice are generally easily distinguished from glacially polished surfaces by the following characteristics. First, drift-ice polished surfaces occur only on relatively soft rocks. The surface is very small compared to a glacially polished surface: a few square meters compared to many hundreds of square meters for glacially polished surfaces. Secondly, the surface, even when wet, has a dull aspect, strongly contrasting with the shining aspect of the glacially polished surface which, in addition, is commonly intensely striated. Another subtle difference is that on a glacially polished surface there is often a thin varnish-like crust, about $1 \mathrm{~mm}$ in thickness, which spalls with weathering. This feature is absent on drift-ice polished surfaces, which closely resemble mechanical abrasion surfaces produced by sand and gravel washed by waves and currents or by a cavitation process in a fluvial environment. 
Thus, because of their entirely different appearance, an experienced geologist can easily distinguish between drift-ice and glacier-ice polished surfaces. However, difficulties may occur if the exposed bedrock surface is small. In such a case, a careful and cautious examination of the surface is necessary.

Despite the relatively common occurrences of drift-ice or iceberg-polished surfaces, there are only a few mentions of this phenomenon in the literature, and many of these are suspicious (Forchhammer, 1847, p. 1177; Hayes, 1868, p. 415; Hind, 1877, p. 230; Loewe, 1935, p. 267; Bird, 1967, p. 221; Dionne, 1970 , p. 176-77). Considering their use in reconstructing the geologic events in an area, drift-ice polished surfaces are still of little interest.

\section{Scratches}

Scratches are surficial abrasion features scattered over rock surfaces (Laverdière and others, 1979). Although varied in form and size, they are usually $2 \mathrm{~mm}$ or less in depth and occupy only very small and scattered areas usually less than a few square decimeters. They reflect the erratic action of drift-ice over a rock surface. These features, of ten reported as striations, are quite frequent along present rocky shorelines (Figs 1 and 2). However, due to the mode of formation, they are rare on glacially polished surfaces which are more commonly dominated by striations, grooves, and

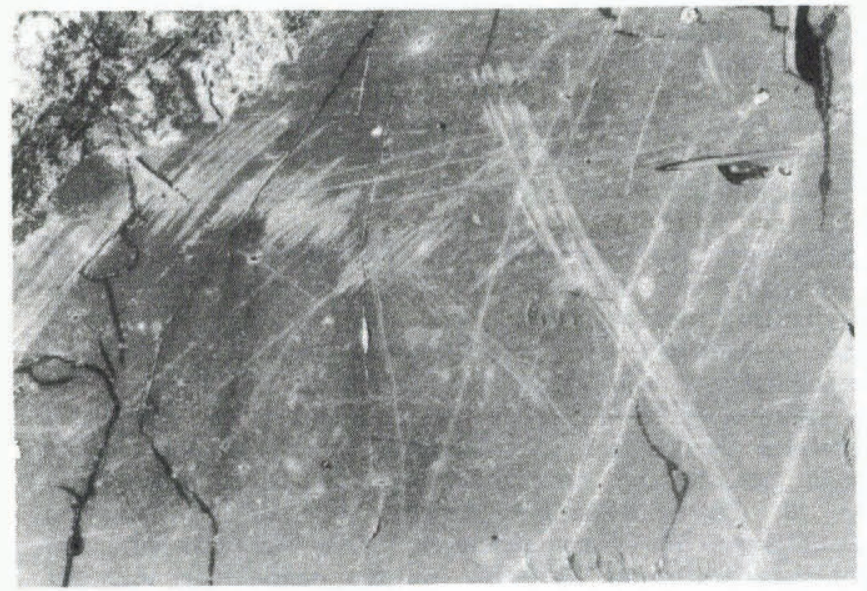

Fig. 1. Recent drift-ice scratches on a glacially polished and striated bedrock surface (basalt) along Manitounuk Peninsula, Hudson Bay. The stylo indicates the glacial direction.

chattermarks. As scratches differ in many aspects from striations, it is useful to classify these abrasion marks in a different category (Laverdière and others, 1979).

\section{Striations and small grooves}

Striations are the commonest drift-ice abrasion feature reported in the literature (Hayes 1868, p. 415; Fielden and de Rance, 1878, p. 486, 556; Garwood, 1899, p. 215; Leiviskă, 1905, p. 216; Leffingwell, 1919, p. 174; Gould, 1928 , p. 37 ; Mathiassen, 1933, p. 32, 69, 94; Frödin, 1956; Strömberg and Sundius, 1956; Ignatius, 1958, p. 11-12; Bird, 1967, p. 221; Strömberg, 1971). Though frequently confused by some authors with glacial striations, they can be distinguished by the following characteristics. First, they usually cover small surfaces of a large exposed bedrock surface. Secondly, in a given locality, they are commonly multi-directional and show a criss-cross pattern (Figs 3-5), contrasting with glacial striations which are usually mostly parallel over long distances. Thirdly, they are usually short (a few centimeters to a few decimeters compared to $1 \mathrm{~m}$ or more), shallow, isolated, intermittent, divergent, discontinuous, and irregular in width, length, and depth. In addition, they are often sinuous, curved, and crooked. Because drift-ice striations are restricted to modern or former coastal areas, their geographical distribution is another distinguishing criterion, since glacial striations can occur widely throughout a glaciated area.
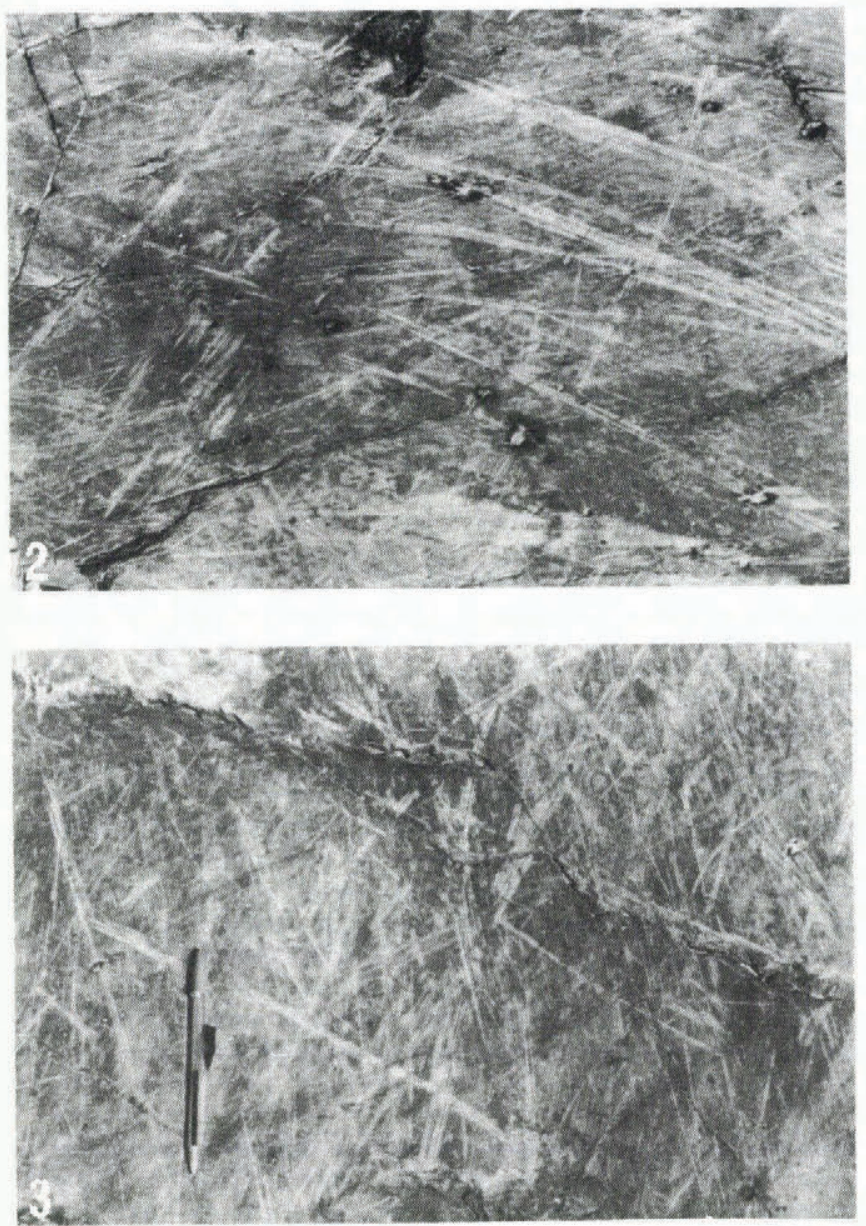

Figs 2 and 3. A shore platform cut in basalt recently scratched and striated by drift ice. These recent abrasion marks are superimposed on former glacial striations whose direction is indicated by the stylo; Manitounuk Peninsula, Hudson Bay.

Russell (1890, p. 117) indicated that on river beds and shores "the scratches are rudely parallel to the direction of the river current, but are not deeply engraved. The scratches are made by sand and pebbles frozen in the ice". A few authors have also provided some characteristics of drift-ice striations (Nansen, 1897, p. 488; Prest, 1901, p. 337-38; Washburn, 1947, p. 47-48; Frödin, 1956, p. 26-29; Strömberg and Sundius, 1956, p. 140-41).

In deeper water, drift-ice striations are also made by icebergs (Geikie, 1882; Chalmers, 1886, 1895; Loewe, 1935; Frödin, 1956). Long ago, Chamberlin (1888, p. 228) mentioned that striations made by icebergs "are curved, crooked, and intermittent, of irregular width and depth". $\mathrm{He}$ also indicated that "curvature of a higher degree than those likely to be produced beneath a glacier would undoubtedly be formed by grounding bergs and floes". However, the distinction between drift-ice and iceberg striations is a difficult task even for an experienced field geologist, particularly in coastal uplifted areas.

In addition to striations, small grooves and even minor friction cracks made by drift ice have been reported recently (Laverdière and others, 1981). Thus the criterion of the absence of friction cracks in small grooves discussed by Frödin (1956) to distinguish between glacial and drift-ice abrasion marks is not conclusive.

Drift-ice striations are also found on rock fragments: boulders, cobbles, and pebbles (Lyell, 1846; Dawson, 1886; Jenness, 1952; Nichols, 1961; Tremblay, 1967). Russell (1890, p. 120) mentioned that "the scratches on the smooth face are less regular and less firmly drawn than grooves and striations on typical glaciated pebbles". The characteristics of drift-ice striations on pebbles, cobbles, and boulders have been provided by Wentworth (1928) and Quéré (1966). 
Despite some differences, it is usually difficult to distinguish between abrasion marks on erratics made by floating ice and glacier ice, particularly when the rock fragments have been transported and redeposited. Along modern shorelines, such as the St. Lawrence Estuary and eastern Hudson Bay, many boulders in the tidal zone are abraded on one face only, i.e. the exposed surface. In this case, it is relatively easy to determine the origin of striations and scratches. As underlined by Flint (1971, p. 95), "a great deal of judgment is needed in the identification of drift-ice abrasion marks on rock surfaces and particularly on erratics".

Drift-ice abrasion marks are usually made by boulders, pebbles, and any other rock fragment frozen at the base of an ice cover or an ice floe, and then pushed along the rock surface by wind, tide, waves, or currents. They are also made by isolated blocks or boulders in a rock platform pushed by shore-ice ride-up and pile-up in a marine and lacustrine environment. Abrasion marks are made either by a movement of boulders in front of drift ice and below it. Depending upon the availability of debris, the characteristics of the rocky shoreline, the nature and the varying direction of the pressure, abrasion marks occur as a scattered feature throughout the surface. They are thus oriented in various directions and have different ages.

\section{DISCUSSION}

Drift-ice abrasion marks are common along the present rocky shorelines of the St. Lawrence Estuary and particularly Hudson Bay. In sub-Arctic Quebec, they occur everywhere along the eastern shore of Hudson Bay, particularly on the gently sloping, volcanic rock (basalt) platforms at Long Island, Manitounuk Islands and Manitounuk Peninsula, Nastapoka Islands, and all along the mainland rocky shoreline (Allard and Tremblay, 1983). They are usually superimposed on the former glacially polished and striated surface. In places, they are so abundant that the former glacially polished and striated surface is difficult to identify (Fig. 3). In many localities, up to eight or nine directions of striations and scratches have been measured. Of course, no more than one or two can be attributed to glacier flow which has a constant direction shifting from $250^{\circ}$ to $300^{\circ}$ in this area (Hillaire-Marcel, 1976). The other directions are thus questionable. Figures 4 and 5 illustrate drift-ice striations superimposed on a glacially polished and striated surface (the stylo points to the glacial flow direction).

It is difficult to understand how a glacier can striate successively a bedrock surface in several directions, preserving at the same time most of the abrasion marks made previously. If a glacier moving over a bedrock surface is able to polish, scratch, striate, or groove it once in a well-defined direction, how can the same glacier, in changing its flow direction several times, subsequently striate again the same bedrock surface such that the first, second,

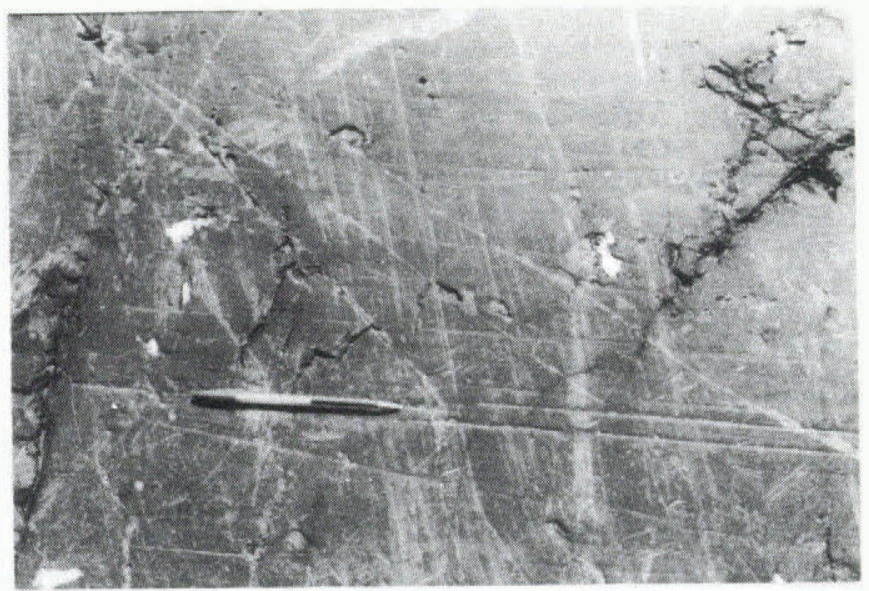

Fig. 4. Criss-cross striations on a shore platform (basalt) along Manitounuk Peninsula, Hudson Bay. The drift-ice striations cross the former glacial set (stylo) at right-angles.

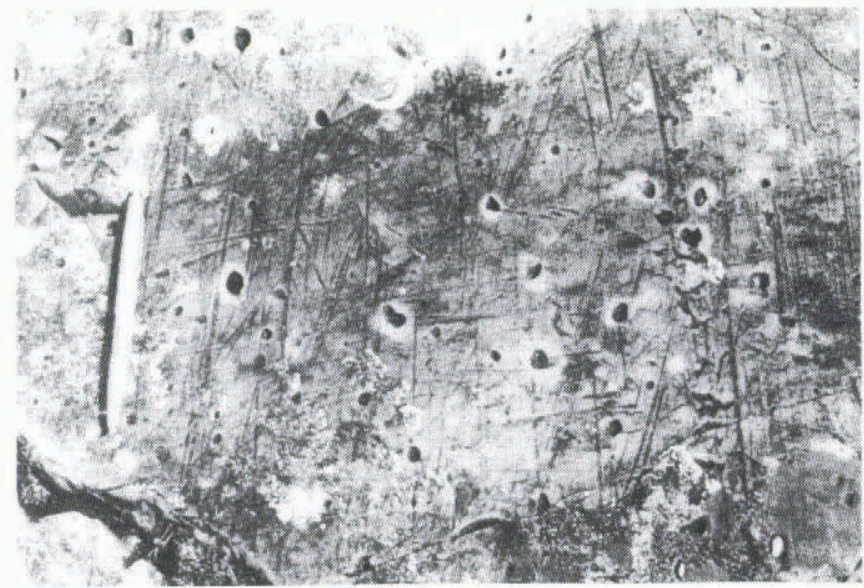

Fig. 5. Sets of glacial and drift-ice striations well preserved on an emerged surface, Manitounuk Peninsula, Hudson Bay. The stylo indicates the former glacial direction.

third, and even fourth sets of striations are partially preserved and not erased? There is a fundamental problem here that has not yet been resolved, possibly because the capacity of a glacier to striate and scratch bedrock surfaces repetitively without erasing the previous marks has not been questioned seriously until recently.

In coastal areas, ice flow of a relatively thin glacier stranded in shallow water is apt to change direction several times according to the calving bergs process. In addition, surficial abrasion marks related to the thinning out of the ice, in combination with the buoyancy effect, can be produced without destroying completely a former striated bedrock surface. As a result, it is likely that two or three sets of well-defined striations are true glacial abrasion marks. However, in this particular environment, multi-directional sets of striations should be regarded as problematic abrasion marks, and the drift-ice hypothesis should, at least, be considered seriously (Frödin, 1956, p. 26-29; Strömberg and Sundius, 1956, p. 140-41).

Because drift-ice processes are erratic and irregular from year to year, the resulting abrasion marks have various orientations related to the direction of ice floes pushed onshore by winds or by pressures from pack ice. As mentioned above, the nature and size of abrasion marks vary considerably from place to place and only small surfaces are scratched or striated at the same time. The relatively small vertical pressures of ice floes compared to those of a glacier permit the formation of new sets of striations and scratches without entirely destroying the older ones. As a result, several sets of striations of different ages can occur at the same site. This is the case along the rocky shorelines of Hudson Bay.

Because drift-ice abrasion marks have not always been considered seriously in the past, at least in North America, some misinterpretations about bedrock striations do exist. For example, up to five sets of striations have been reported by Legget (1980) at Grand Manan Island, Bay of Fundy, and up to eight directions have been recorded by Andrews and Falconer (1969) at Ottawa Islands, Hudson Bay. The multi-directional striations at these two localities were considered exclusively as glacial abrasion marks related to very "excited" glaciers moving successively in various directions during the deglaciation of these areas. Since the drift-ice hypothesis was not discussed or even suggested, it is questionable whether glaciers produce all the striation sets reported. It is worthwhile mentioning that these islands have been largely dominated by drift-ice processes since deglaciation.

In other areas, the situation is more complex and misinterpretations may have resulted. This is the case for Hopen Island, Svalbard (Hoppe and others, 1969), where scattered striations occurring on rocky shorelines were used first to indicate Pleistocene glaciation. In a recent paper, Hoppe $(1981$, p. 68) recognized that "the striae most probably are an effect of movement of drift or pack ice on the shore, a common feature in Swedish coastal areas". It is 
relevant to mention here that in Scandinavia many glacial geologists (Leiviskă, 1905; Frödin, 1956; Strömberg and Sundius, 1956; Strömberg, 1971), having worked in coastal areas where well-exposed bedrock surfaces occur, have recognized and discussed the drift-ice hypothesis in the case of problematical abrasion marks.

The criss-cross and multi-directional striations and scratches which occur on a limestone outcrop in New York State, as reported by Ritter $(1978$, p. 379$)$, are so similar to the drift-ice striations found along the rocky shorelines of Hudson Bay (Figs 4 and 5) that it is difficult to attribute all of them to variations in the glacial flow direction during the late Pleistocene. In the same way, the drag-mark casts on Precambrian sandstones in Australia as reported by Milton (1966, p. 293), could also be attributed to drift-ice rather than to drifting algae, because no kelp is known to have existed at that period, while glaciations have been reported during Precambrian time in Australia (Harland and Herod, 1975; Young, 1979).

Finally, it is useful to point out that variations in the direction of ice flow may reflect purely local bedrock influence, i.e. bedrock irregularities which deflect ice flow. As a result, it is likely that in a given locality two or three sets of striations effected by the same glacier could be explained without invoking the drift-ice hypothesis. However, these striations are rarely superimposed and seldom intersect at right-angles.

\section{CONCLUSIONS}

Drift-ice abrasion marks along modern shorelines are quite common. The purpose of this paper is to focus the attention of Quaternary geologists, not yet aware of the problem, on the occurrence of such features not only along present-day shorelines but also on any former marine and lacustrine shorelines. With this in mind, it is suggested that many ambiguous or problematical so-called glacial striations (McLellan, 1971) reported in the past could perhaps be satisfactorily explained without the necessity of involving several changes in the direction of the glacier ice flow in a given locality during the late Pleistocene. Any set of striations restricted to a small surface and differing in direction from other glacially oriented features, such as streamlined outcrops, stoss-and-lee features, crag-and-tails, and chattermarks, and not related to local bedrock irregularities, should be questioned seriously in areas which have been submerged during late- and post-glacial time. Consequently, a re-examination of the data presented in some reports is necessary for a more adequate glacier ice-flow reconstruction in many coastal areas.

\section{ACKNOWLEDGEMENTS}

The author gratefully acknowledges the financial assistance of the National Research Council of Canada (NSERC Programs) and the Centre d'Études Nordiques for field work along Hudson Bay and the St. Lawrence Estuary shorelines. P.B. Clibbon (Université Laval) has reviewed a first draft of this paper, while C. Laverdière and P. Guimont (Université de Montréal), and D.R. Grant (Geological Survey of Canada) provided useful information and discussion. M.K. Seguin (Department of Geology, Université Laval) helped in translating some Swedish papers. The author appreciates very much the useful comments and remarks made by three unidentified referees.

\section{REFERENCES}

Allard, M., and Tremblay, G. 1983. Les processus d'érosion littorale et périglaciaire de la région de Poste-de-la-Baleine et des iles Manitounuk sur la côte est de la mer d'Hudson. Zeitschrift für Geomorphologie, Supplement 1, Bd. 47, p. 27-60.

Andrews, J.T., and Falconer, G. 1969. Late glacial and post-glacial history and emergence of the Ottawa Islands, Hudson Bay, Northwest Territories: evidence on the deglaciation of Hudson Bay. Canadian Journal of Earth Sciences, Vol. 6, No. 5, p. 1263-76.
Bird, J.B. 1967. The physiography of Arctic Canada, with special reference to the area south of Peary Channel. Baltimore, MD, Johns Hopkins Press.

Chalmers, R. 1886. On the glaciation and Pleistocene subsidence of northern New Brunswick and south-eastern Quebec. Transactions of the Royal Society of Canada, Vol. 4, Sec. 4, p. 139-45.

Chalmers, R. 1895. Report on the surface geology of New Brunswick, northern Nova Scotia and a portion of Prince Edward Island. Geological Survey of Canada. Annual Report 1894, Vol. 7, Pt. M.

Chamberlin, T.C. 1888. The rock-scorings of the great ice invasions. U.S. Geological Survey. 7th Annual Report, [for the year] 1885-86, p. 147-248.

Dawson, J.W. 1886. Note on boulder drift and sea margins at Little Metis, lower St. Lawrence. Canadian Record of Science, Vol. 2, No. 1, p. 36-38.

Dionne, J.-C. 1970. Aspects morpho-sédimentologiques du glaciel, en particulier des côtes du Saint-Laurent. Ste-Foy, Québec, Laboratoire de Recherches Forestières. (Rapport d'Information Q-F-X-9.)

Dionne, J.-C. 1973. Distinction entre stries glacielles et stries glaciaires. Revue de Géographie de Montréal, Vol. 27, No. 2, p. $185-90$.

Dionne, J.-C., and others. 1983. Drift-ice abrasion marks along rocky shores, Hudson Bay, Canada, by J.-C. Dionne, C. Lavardière, and P. Guimont. Geological Society of America. Abstracts with Programs, Vol. 15, No. 3, p. 126.

Embleton, C., and King, C.A.M. 1975. Glacial geomorphology. [Glacial and periglacial geomorphology. Second edition. Vol. 1.] London, Edward Arnold.

Feilden, H.W., and De Rance, C.F. 1878. Geology of the coasts of the Arctic lands visited by the late British Expedition under Captain Sir George Nares. Quarterly Journal of the Geological Society of London, Vol. 34, p. 556-67.

Flint, R.F. 1971. Glacial and Quaternary geology. New York, John Wiley and Sons, Inc.

Forchhammer, J.G. 1847. Nouvelles observations de M. Forchhammer sur les surfaces striées du Danemark. Bulletin de la Société Géologique de France, Sér. 2, Tom. 4, p. 1177-84.

Frödin, G. 1956. Isströmssuccessionen på Uplandshalvőn jämte försök till korrelation med Ålands och Ábolands skärgård. Geographica (Uppsala), Vol. 32.

Garwood, E.J. 1899. Additional notes on glacial phenomena in Spitsbergen. Quarterly Journal of the Geological Society of London, Vol. 55, p. 681-90.

Geikie, J. 1882. The great ice age, and its relation to the antiquity of Man. New York, Appleton.

Gould, L.M. 1928. The Putnam Baffin Island expedition. Report on the physical geography. Geographical Review, Vol. 18, No. 1, p. 27-40.

Harland, W.B., and Herod, K.N. 1975. Glaciations through time. (In Wright, A.E., and Moseley, F., ed. Ice ages: ancient and modern. The proceedings of the 21st Inter-University Geological Congress held at the University of Birmingham, 2-4 January 1974. Liverpool, Seel House Press, p. 189-216.)

Hayes, J.J. 1868. La mer libre du pôle. Voyage de découverte dans les mers arctiques. Paris, Hachette.

Hillaire-Marcel, C. 1976. La déglaciation et le relèvement isostatique sur la côte est de la baie d'Hudson. Cahiers de Géographie de Québec, Vol. 20, No. 50, p. 185-220.

Hind, H.Y. 1877. Note on some geological features of the northeastern coast of Labrador. Canadian Naturalist, Vol. 8 , No. 4 , p. $227-40$.

Hoppe, G. 1981. Glacial traces on the island of Hopen, Svalbard: a correction. Geografiska Annaler, Vol. 63A, Nos. 1-2, p. 67-68.

Hoppe, G., and others. 1969. Studies of the glacial history of Hopen (Hopen Island), Svalbard, by G. Hoppe, V. Schytt, A. Häggblom, and H. Österholm. Geografiska Annaler, Vol. 51A, No. 4, p. 185-92.

Ignatius, H. 1958. On the Late-Wisconsin deglaciation in eastern Canada. Acta Geographica, Vol. 16, No. 3.

Jenness, J.L. 1952. Problem of glaciation in the western islands of Arctic Canada. Bulletin of the Geological Society of America, Vol. 63, No. 9, p. 939-52. 
Laverdière, C., and others. 1979. Marks and forms on glacier beds: formation and classification, by C. Laverdière, P. Guimont, and M. Pharand. Journal of Glaciology, Vol. 23, No. 89, p. 414-16.

Laverdière, C., and others. 1981. Marques d'abrasion glacielles en milieu littoral hudsonien, Québec subarctique, by C. Lavardière, P. Guimont, and J.-C. Dionne. Géographie Physique et Quaternaire, Vol. 35, No. 2, p. 269-75.

Leffingwell, E. de K. 1919. The Canning River region, northern Alaska. U.S. Geological Survey. Professional Paper, No. 109.

Legget, R.F. 1980. Glacial geology of Grand Manan Island, New Brunswick. Canadian Journal of Earth Sciences, Vol. 17, No. 4, p. 440-52.

Leiviskä, I. 1905. Über die Küstenbildungen des Bottnischẹn Meerbusens zwischen Tornio und Kokkola. Fennia, Vol. 23, No. 1.

Loewe, F. 1935. Central western Greenland: the country and its inhabitants. Geographical Journal, Vol. 86, No. 3, p. 263-75.

Lyell, C. 1846. On the packing of the ice in the River St. Lawrence. Quarterly Journal of the Geological Society of London, Vol. 2, p. 422-27.

McLellan, A.G. 1971. Ambiguous "glacial" striae formed near waterbodies. Canadian Journal of Earth Sciences, Vol. 8, No. 4, p. 477-79.

Mathiassen, T. 1933. Contributions to the geography of Baffin Land and Melville Peninsula. Copenhagen, Gyldendalske Boghandel, Nordisk Forlag. (Report of the Fifth Thule Expedition 1921-24, Vol. 1, No. 3.)

Milton, D.J. 1966. Drifting organisms in the Precambrian sea. Science, Vol. 153, No. 3733, p. 293-94.
Nansen, F. 1897. Some results of the Norwegian Arctic Expedition, 1893-96. Geographical Journal, Vol. 9, No. 5, p. 473-505.

Nichols, R.L. 1961. Characteristics of beaches formed in polar climates. American Journal of Science, Vol. 259, No. 9, p. 694-708.

Prest, W.H. 1901. On drift ice as an eroding and transporting agent. Transactions of the Nova Scotia Institute of Sciences, Vol. 10, p. 333-44.

Quéré, J. 1966. Blocs striés quaternaires non glaciaires près de Paris. Cahiers Géologiques, Nos. 81-82, p. 933-55.

Ritter, D.F. 1978. Process geomorphology. Dubuque, IA, Wm. C. Brown.

Russell, I.C. 1890. Notes on the surface geology of Alaska. Bulletin of the Geological Society of America, Vol. 1, p. 99-162.

Strömberg, B. 1971. Isrecessionen i området kring Ålands Hav. Stockholms Universitet. Naturgeografiska Institutionen. Forskningsrapport, No. 10.

Strömberg. B., and Sundius, K. 1956. Studier av isräfflor och glacialskulptur i Stockholms skärgård. Ymer, Vol. 76, Ht. 2, p. 133-53.

Tremblay, G. 1967. Observations et mesures sur les blocs glaciels du cap à l'Orignal. Cahiers de Géographie de Québec, Vol. 11, No. 23, p. 402-11.

Washburn, A.L. 1947. Reconnaissance geology of portions of Victoria Island and adjacent regions, Arctic Canada. Geological Society of America. Memoir 22.

Wentworth, C.R. 1928. Striated cobbles in southern states. Bulletin of the Geological Society of America, Vol. 39, No. 12 , p. 941-54.

Young, G. 1979. The earliest ice ages: Precambrian. (In John, B.S., ed. The winters of the world; Earth under the ice ages. New York, Halsted Press (Wiley), p. 107-30.) 